\title{
Evaluation of Blood Lead Levels and Their Effects on Hematological Parameters and Renal Function in Iranian Lead Mine Workers
}

\author{
Razzagh Rahimpoor ${ }^{\mathbb{D}}{ }^{1}$, Maryam Rostami ${ }^{2}$, Mohammad Javad Assari (iD) ${ }^{3}$, Ahmad Mirzaei ${ }^{4}$ and \\ Mohammad Reza Zare (iD) ${ }^{5,}$ \\ ${ }^{1}$ Department of Occupational Health Engineering, Research Center for Health Sciences, School of Health, Larestan University of Medical Sciences, Larestan, Iran \\ ${ }^{2}$ Department of Occupational Health Engineering, School of Public Health, Tehran University of Medical Sciences, Tehran, Iran \\ ${ }^{3}$ Department of Occupational Health Engineering, Research Center for Health Sciences, School of Health, Hamadan University of Medical Sciences, Hamadan, Iran \\ ${ }^{4}$ Department of Occupational Health and Safety Engineering, Research Center for Health Sciences, School of Health, Shiraz University of Medical Sciences, Shiraz, Iran \\ ${ }^{5}$ Department of Environmental Health Engineering, Ewaz School of Health, Larestan University of Medical Sciences, Larestan, Iran \\ Corresponding author: Department of Environmental Health Engineering, Ewaz School of Health, Larestan University of Medical Sciences, Larestan, Iran. Email: \\ zaremohammad1363@yahoo.com
}

Received 2019 July 14; Revised 2020 August 09; Accepted 2020 October 05.

\begin{abstract}
Background: Lead toxicity has become a growing health concern in countries such as Iran. However, little information is available on the assessment and evaluation of the health effects of lead exposure in mine workers.

Objectives: The present study assessed the occupational exposure to lead and examine the association of blood lead ( $\mathrm{PbB}$ ) levels with hematological and kidney function parameters in mine workers.

Methods: In this matched case-control study, the level of $\mathrm{PbB}$ was measured in 100 workers (70 exposed and 30 non-exposed), and then its relationship was evaluated with complete blood count (CBC) parameters, zinc protoporphyrin (ZPP), urea, blood creatinine levels, urinary $\delta$-aminolevulinic acid (ALA), coproporphyrin, and creatinine levels.

Results: The results showed a linear and significant relationship between the PbB level and B-ZPP, U-ALA, U-coproporphyrin, and U-creatinine levels in states of PbB levels $>20 \mu \mathrm{g} / \mathrm{dL}$ in a time and dose-dependent manner. A significant relationship was observed between the $\mathrm{PbB}$ level and the years of occupational exposure to lead and the B-urea level (P-value $<0.03$ ).

Conclusions: Chronic occupational exposure to lead decreased hematocrit, RDW-CV, MCV, MCH, and HGB values but did not significantly change RBC counts. Therefore, a regular assessment of routine blood parameters (such as CBC and ZPP) and renal function indices can be effectively used to monitor the toxic effects of lead exposure.
\end{abstract}

Keywords: Biomonitoring, Blood, Lead Poisoning, Occupational Exposure

\section{Background}

Workers in their workplace can be potentially exposed to a wide range of harmful occupational factors, including chemicals (dust, gases, and vapors), physical hazards (noise, ionizing radiation, and inappropriate weather conditions), and psychological and ergonomic factors (stress and high mental workload). Exposure to these agents can cause a variety of occupational complications and diseases in workers, such as respiratory diseases, musculoskeletal disorders, physiological disorders, and cancers (1-4).

Exposure to lead $(\mathrm{Pb})$ can be the oldest known occupational health hazard. Occupational exposure to lead occurs via the inhalation of lead-containing dust and fumes and ingestion tracts (eating food contaminated with lead compounds) $(5,6)$. Acute or chronic exposure to lead occurs in various industries such as mining, smelting, battery, foundry, glass, and ceramics. Lead toxicity has been reported in different biological systems and functions (7). Overexposure to lead is associated with anemia, high blood pressure, impotence, infertility, and reduced sexual performance, as well as damage to the kidneys and nervous system (8). The carcinogenic effects of lead on humans are unknown, but the International Agency for Research on Cancer (IARC) has classified lead and inorganic lead compounds in Group 2B (as possible human carcinogens) (9).

It has been reported that acute exposure to a high concentration of lead can cause proximal tubular damage, glycosuria, and aminoaciduria. Moreover, chronic occupational exposure to lead is associated with a high incidence of renal dysfunction, which is characterized by glomerular and tubulointerstitial changes (changes in blood and urinary creatinine and blood urea levels), resulting in chronic 
renal failure, hypertension, hyperuricemia, and gout (10, 11).

The critical effects of lead in the body are mainly attributed to its interference with numerous enzymes involved in heme synthesis, such as the inhibition of $\delta$-aminolevulinic acid dehydratase (ALAD), and changes in some metabolite concentrations (e.g., deltaaminolevulinic acid in the urine (ALA-U), coproporphyrin in urine (CP), and zinc protoporphyrin (ZPP) in the blood). Thus, they can be used as markers for the effects of overexposure to lead. Also, lead can shorten the lifespan of red blood cells (RBCs) and subsequently increase the risk of reticulocytosis and anemia $(12,13)$. Although chronic exposure to lead can affect the complete blood count (CBC), the effectiveness of using these para-clinical markers in the evaluation of occupational diseases caused by lead exposure has not been well known $(14,15)$.

Mining is one of the hard, harmful, and dangerous occupations, and miners are facing many serious health hazards (16). Iran is home to 68 types of minerals, including copper, gold, coal, iron, lead, zinc, chromium, molybdenum barite, salt, gypsum, and rare-earth elements. Iran has the largest combined reserves of lead and zinc, with 11 million tons of zinc and 222 million tons of lead and zinc ores (17-19).

Although many efforts have already been made to control lead exposure in mines, its environmental toxicity and occupational exposure are still challenging in the United States of America as a developed country. On the other hand, lead toxicity is also an important health issue in developing countries such as Iran, but despite a large number of mine workers, little information is available on the assessment of the associated health effects in these workers. This can be due to financial constraints and limitations in access to advanced equipment for the biological monitoring of environmental and occupational exposure to toxic metals. Aiming to address the prevalence of leadinduced disturbances, the present study focused on the biological monitoring (exposure-effects) of workers in lead mining enterprises. The selected mine is one of the largest lead mines in Iran and the only major source of minerals in this country (Figure 1 ).

\section{Objectives}

Due to lead poisoning and its adverse health effects, this cross-sectional study aimed to assess occupational exposure to lead to examine the association of occupational lead concentration in blood ( $\mathrm{PbB}$ ) levels and hematological parameters and kidney function in mine workers.

\section{Methods}

\subsection{Study Population}

This matched case-control study was performed in the lead mine complex in East Iran in 2018. All male workers in the mine were included in the study $(n=140)$. The recruitment and selection of study subjects were based on their medical history. The exclusion criteria were a work experience of lower than one year, having a second job, and having inherited hematological, renal, infectious, allergic, rheumatic, diabetic, hypertensive, and mental- behavioral diseases. Finally, 100 participants were found to match based on age and work experience and divided into two groups. Totally, 70 workers with occupational exposure to lead were selected as the exposed group, and 30 healthy volunteers without occupational exposure to lead were selected as the non-exposed group. A self-reporting questionnaire was used to collect potential confounders. These factors included age, weight, employment duration, cigarette use, alcohol intake, and average duration of daily exposure to lead sources.

\subsection{Ethics}

The present study was reviewed and approved before the study began in 2018 by the Institutional Review Board and Ethics Committee of Larestan University of Medical Sciences (Ethical code: IR.LARUMS.REC.1396.223), and written informed consent was obtained from the participants. Permission was obtained from the mine authorities, and the purpose of the study was explained to all participants. They were also assured of data confidentiality and all samples and questionnaires were kept anonymous.

\subsection{Blood and Urine Sample Collection}

All urine and blood samples from the participants were collected at the end of the workweek shift. Plain tubes were used to obtain serum samples, and vacuum tubes containing $\mathrm{K}_{3}$ EDTA (Frickenhausen, Germany) to collect blood samples. A $24 \mathrm{~h}$ urine collection was done by collecting workers' urine in special containers over a full $24 \mathrm{~h}$ period. Urine and blood samples were frozen and kept at $-20^{\circ} \mathrm{C}$ until transfer to a toxicology laboratory for assay.

\subsection{Lead Concentration in Blood}

An atomic absorption spectrophotometer (model 900T, Perkin Elmer) equipped with Deuterium Background Corrector and graphite furnace was used to determine $\mathrm{PbB}$ concentrations. Blood sample pre-treatment consisted of a five-fold dilution with a dilute surfactant. Simultaneous background correction was used to eliminate small and non-specific absorption signals from the blood matrix. The lead levels in blood were accurately measured in $20 \mu \mathrm{L}$ blood samples at a wavelength of $283.3 \mathrm{~nm}$. 


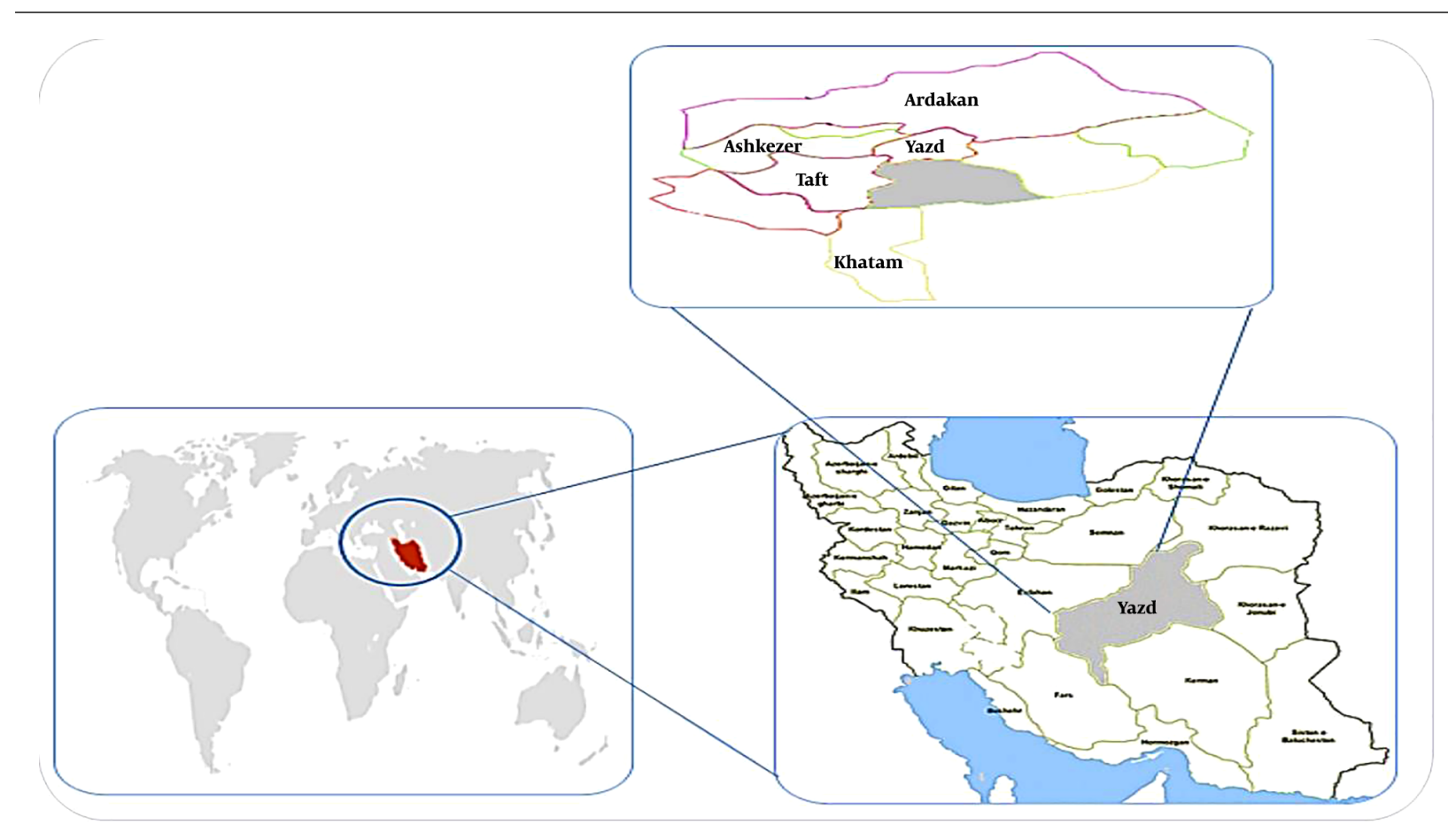

Figure 1. Location of study

\subsection{Complete Blood Count, Blood Urea, and Urine Creatinine}

The CBC was determined using a quantitative automated hematology analyzer (Sysmex model: XS 800i). The analysis included white blood cell (WBC) count, RBC count, hemoglobin (HGB), hematocrit (HCT), mean corpuscular hemoglobin mass $(\mathrm{MCH})$, mean corpuscular volume (MCV), mean corpuscular hemoglobin concentration (MCHC), red blood cell distribution width-coefficient of variation (RDW-CV), platelet distribution width (PDW), platelet (PLT) count, mean platelet volume (MPV), neutrophil, lymphocyte, eosinophil, and monocyte percentages. The concentrations of blood urea (B-U) and urine creatinine (U-C) were measured using the colorimetric method by a UV-Vis spectrophotometric device (Lambda 950, Perkin Elmer).

\subsection{Urinary Delta-Aminolevulinic Acid}

The urinary $\delta$-ALA concentration was measured using a High-Performance Liquid Chromatography device (Waters Alliance: Model 2695) equipped with a fluorometric detector (Waters Alliance: Model 2475). Urinary deltaaminolevulinic acid (U-ALA) is converted into a fluorescent derivative by heating a mixture of the urine sample, diluted acetic acid, formaldehyde solution, and acetylacetone at $100^{\circ} \mathrm{C}$ for $10 \mathrm{~min}$. Its derivative was determined sep- arately using HPLC. The fluorescence intensity was set at 370/460 nm (excitation/emission) (20).

\subsection{Urine Coproporphyrin and Blood Erythrocyte Zinc Protopor- phyrin}

High-performance liquid chromatography (Waters Alliance: Model 2695) equipped with a fluorometric detector (Waters Alliance: Model 2475) was applied to determine the level of urine coproporphyrin (U-C). In this method, 0.5 $\mathrm{mL}$ urine was mixed with an equal volume of acetic acid, and then $25 \mu \mathrm{L}$ of the resulting mixture was used for $\mathrm{CP}$ analysis. The fluorescence intensity was set at $400 / 620 \mathrm{~nm}$ (excitation/emission) (21). The concentration of blood erythrocyte zinc protoporphyrin (B-ZPP) was determined using the fluorimetric method (Hemato fluorimeter, Syemex, $X S 1000 i)$. The fluorometric detector determined the ratio of ZPP concentration as fluorizing substance $(594 \mathrm{~nm})$ to light-absorbing hemoglobin concentration $(420 \mathrm{~nm})$, the results of which were expressed in $\mu \mathrm{g} / \mathrm{dL}$.

\subsection{Statistical Analysis}

Data analysis was performed using SPSS version 19.0 software. To analyze the collected data, we utilized appropriate descriptive and analytical statistics such as mean, standard deviation, relative frequency, one-way ANOVA, 
Mann-Whitney U test, Kolmogorov-Smirnov (KS) test, Student's $t$ test, Kruskal-Wallis test, and chi-square test. The values of the correlation coefficient were determined by Pearson's correlation and multivariate linear regression analysis. In the regression analyses, the dependent variable was the PbB. Odds ratios with $95 \%$ confidence intervals (CIs) were reported for the investigation of the association between the $\mathrm{PbB}$ level and the duration of occupational exposure to lead after controlling for potential confounders (age, weight, smoking, and alcohol consumption) with rate change of biomarkers level. The level of significance was set at $\mathrm{P}<0.05$.

\section{Results}

In this study, the mean age of exposed and non-exposed workers was $34.47 \pm 6.73$ and the daily exposure time to lead in exposed and non-exposed workers was $34.47 \pm 6.73$ and $34.93 \pm 6.68$ years $(P$-value $=0.98)$. The mean time of daily exposure to lead in the exposed and non-exposed workers was $34.47 \pm 6.73$ and 8.61 and $0.00 \mathrm{~h}$, respectively (P-value $=0.001)$. The average body weight of exposed and non-exposed workers was $70.09 \pm 5.82$ and $71.15 \pm$ $6.3 \mathrm{~kg}$, respectively (P-value $=0.93)$. There was no significant difference in age and weight between the exposed and non-exposed groups. Moreover, there was no difference in smoking behavior between the exposed and non-exposed groups $(\mathrm{P}$-value $=0.97)$. As shown in Figure 2, the mean PbB level was three times higher in the exposed group than in the non- exposed group (25.88 and $8.50 \mu \mathrm{g} / \mathrm{dL}$, respectively; P-value < 0.01).

The findings indicated that in the exposed group, some CBC parameters including HGB (1.76\%; $\mathrm{P}=0.02)$, HTC (1.15\%; $\mathrm{P}<0.03), \mathrm{MCV}(2.67 \% ; \mathrm{P}=0.02), \mathrm{MCH}(2.04 \% ; \mathrm{P}<0.002)$, MCHC (3.5\% (P < 0.001), PLT (4.15\%; P < 0.001), RDW-CV (3.44\%; P < 0.002), and PDW (9.37\%; P < 0.001) were significantly lower than those in non-exposed workers. Furthermore, the levels of WBC, RBC, MPV, eosinophil, and monocyte were higher in the case group than in the control group by 6.51\% $(\mathrm{P}<0.003), 6.33 \%(\mathrm{P}<0.003), 11.5 \%(\mathrm{P}$ $<0.002), 28.76 \%(\mathrm{P}<0.001)$, and 11.9\% $(\mathrm{P}<0.002)$, respectively (see Table 1 ).

The results showed significant relationships between the years of occupational exposure to lead and $\mathrm{MCV}, \mathrm{MCH}$, and PLT levels (P-values $=0.005,0.005$, and 0.005, respectively). Also, there were significant relationships between the PbB level and MPV and the eosinophil percentage (Pvalues $=0.035$ and 0.001 , respectively) (see Table 2 ).

The correlation analysis for the case or exposed group showed a positive correlation between the $\mathrm{PbB}$ level and some $\mathrm{CBC}$ parameters such as $\mathrm{RBC}, \mathrm{WBC}, \mathrm{MCHC}, \mathrm{HCT}$, and MPV. As observed, the levels of these parameters increased by increasing the PbB levels $(\mathrm{R}=0.31,0.33,0.15,0.28$, and 0.28 , respectively, P-values $\leq 0.045$ ). Also, there were negative correlations between the $\mathrm{PbB}$ level and some $\mathrm{CBC}$ parameters such as RDW-CV $(\mathrm{r}=-0.20$, P-value $=0.05)$, PDW $(\mathrm{r}=-0.57$, P-value $=0.03)$, lymphocyte $(\mathrm{r}=-0.39$, $\mathrm{P}$-value $=$ $0.043)$, and eosinophil $(r=-0.44$, P-value $=0.05)$. The result showed that the relationships between lead exposure and MCV, MCH, and PLT depended on the exposure duration. Thus, with each one-year increase in chronic exposure to lead, the MCH, MCV, and PLT indices decreased by 0.153 , 0.377 , and 2.74 units, respectively (Table 2). Moreover, the results implied that for each unit increase in the PbB level, the MPV index decreased by 0.02 units and the eosinophil percentage increased by 0.023 units (Table 2).

The analysis of the data confirmed that all blood synthesis indices (U-ALA, B-ZPP, and U-Coproporphyrin) were significantly higher in the exposed subjects than in the non-exposed group $(\mathrm{P}<0.001)$. The concentration of $\mathrm{B}$ ZPP in exposed workers was twice higher than that in nonexposed workers (200.57 and $109.77 \mu \mathrm{g} / \mathrm{dL}$, respectively). In addition, in the non-exposed group, mean U-ALA was 2.6 times higher than in the control group (3.780 and 1.403 $\mathrm{mg} / \mathrm{L}$, respectively) (see Figure 2).

Linear regression analysis revealed a positive correlation between the concentration of B-ZPP and some CBC parameters, including HGB, MCHC, and HCT ( $\mathrm{r}=0.26,0.34$, and 0.37 , respectively). On the other hand, an inverse relationship was observed between B-ZPP and some CBC parameters, including $\mathrm{MCV}, \mathrm{MCH}$, and PDW. Therefore, the levels of these parameters decreased with increasing the BZPP level $(r=-0.45,-0.37$, and -0.29 , respectively). Moreover, the results indicated significant relationships between the PbB levels and U-ALA, U-coproporphyrin, and B-ZPP(P-value $<0.001$ ) after controlling for potential confounders (Table 3).

The mean B-creatinine level was higher in the exposed group than in the non-exposed group $(2.09 \pm 0.03$ and $1.07 \pm 0.02 \mathrm{~g} / \mathrm{L}$, respectively, P-value $<0.04$ ), and the Ucreatinine concentration was significantly higher in the exposed group than in the non-exposed group $(3.80 \pm 0.18$ and $1.40 \pm 0.17 \mathrm{~g} / 24 \mathrm{~h}$, respectively, P-value < 0.03). The results demonstrated that regardless of confounding factors, there was no significant relationship between the $\mathrm{PbB}$ level and B-Creatinine and urea concentrations in mine workers ( $\mathrm{r}=0.19$ and 0.01 , respectively). However, the results indicated a linear and significant relationship between the $\mathrm{PbB}$ level of mine workers and B-Creatinine and B-urea concentrations ( $r=0.59$ and 0.70 , respectively). 

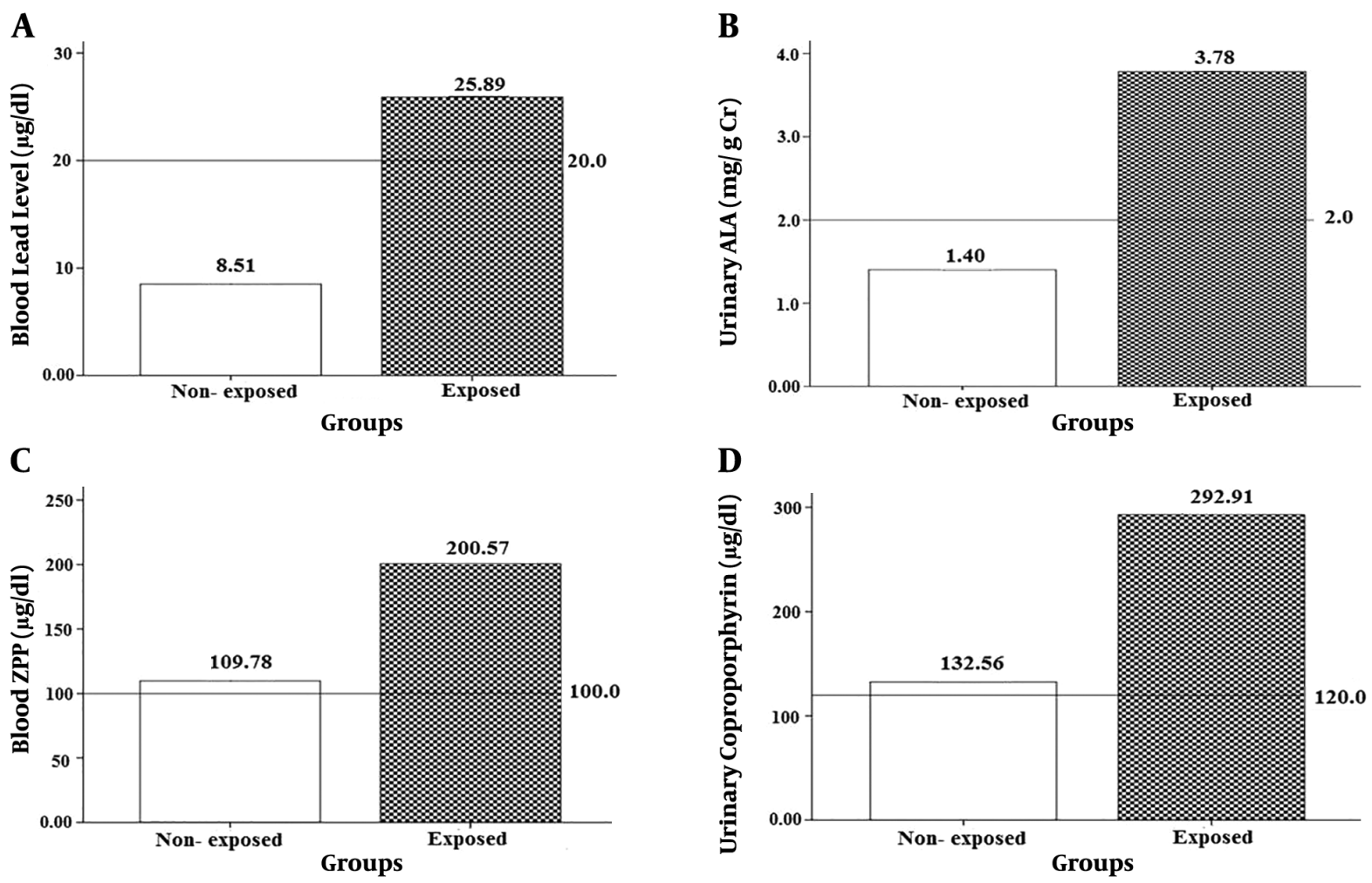

Figure 2. The concentration of (A) PbB (5.78 - $33.20 \mu \mathrm{g} / \mathrm{dL})$, (B) U-ALA (0.0 - $6.28 \mathrm{mg} / \mathrm{g}$ crea), (C) B-ZPP (0.0 - 291.98 $\mu \mathrm{g} / \mathrm{dL})$, and (D) U-Coproporphyrin (0.0 - 416.67 $\mu \mathrm{g} / \mathrm{dL})$ in the exposed and non-exposed groups.

\begin{tabular}{|c|c|c|c|c|c|c|c|c|c|}
\hline \multirow{2}{*}{ CBC Parameter } & \multicolumn{3}{|c|}{ Non-Exposed $(\mathbf{N}=\mathbf{3 0})$} & \multicolumn{3}{|c|}{$\operatorname{Exposed}(N=70)$} & \multirow{2}{*}{ Difference (\%) } & \multirow{2}{*}{ Normal } & \multirow{2}{*}{ P-Value } \\
\hline & Mean $\pm S D$ & Max & Min & Mean \pm SD & Max & Min & & & \\
\hline $\operatorname{WBC}\left(\times 10^{3} \mid \mu \mathrm{I}\right)$ & $7.06 \pm 0.17$ & 9.20 & 4.70 & $7.52 \pm 0.16$ & 9.90 & 4.40 & 6.51 & $3.5-11$ & 0.003 \\
\hline $\operatorname{RBC}\left(\times 10^{6} \mid \mu 1\right)$ & $5.05 \pm 0.08$ & 6.44 & 4.45 & $5.37 \pm 0.04$ & 6.08 & 4.83 & 6.33 & $3.6-6.1$ & 0.003 \\
\hline $\mathrm{HGB}(\mathrm{g} / \mathrm{dl})$ & $15.82 \pm 0.23$ & 16.10 & 12.00 & $15.54 \pm 0.10$ & 17.60 & 12.80 & -1.76 & $11.5-18.8$ & 0.02 \\
\hline HCT (\%) & $47.69 \pm 0.16$ & 53.50 & 39.40 & $47.14 \pm 0.29$ & 52.70 & 39.70 & -1.15 & $34-54$ & 0.03 \\
\hline $\operatorname{MCV}(\mathbf{f l})$ & $85.98 \pm 1.01$ & 93.40 & 67.80 & $83.68 \pm 0.59$ & 96.10 & 70.40 & -2.67 & $80-100$ & 0.02 \\
\hline MCH (pg) & $28.87 \pm 0.43$ & 31.90 & 20.70 & $28.28 \pm 0.24$ & 32.00 & 22.70 & -2.04 & $27-36$ & 0.002 \\
\hline MCHC (g/dl) & $33.27 \pm 0.14$ & 34.80 & 30.50 & $32.12 \pm 0.08$ & 34.90 & 31.80 & -3.45 & $32-36$ & 0.001 \\
\hline $\operatorname{PLT}\left(\times 10^{3} \mid \mu 1\right)$ & $234.63 \pm 5.97$ & 294.00 & 150.00 & $224.87 \pm 6.1$ & 334.0 & 82.00 & -4.15 & $150-450$ & 0.001 \\
\hline RDW-CV (\%) & $13.35 \pm 0.1$ & 14.60 & 11.60 & $12.89 \pm 0.07$ & 14.70 & 11.40 & -3.44 & $11.6-14.6$ & 0.002 \\
\hline PDW (\%) & $17.72 \pm 0.07$ & 18.60 & 16.90 & $16.04 \pm 0.07$ & 19.10 & 16.70 & -9.37 & $7 \cdot 20$ & 0.001 \\
\hline Neutrophils (\%) & $55.33 \pm 1.19$ & 65.00 & 45.00 & $55.70 \pm 1.13$ & 74.00 & 38.00 & 0.66 & - & 0.01 \\
\hline Lymphocytes (\%) & $38.33 \pm 1.10$ & 49.00 & 30.00 & $38.44 \pm 1.08$ & 56.00 & 21.00 & 0.3 & - & 0.01 \\
\hline Eosinophils(\%) & $1.46 \pm 0.10$ & 3.00 & 1.00 & $1.88 \pm 0.07$ & 3.00 & 1.00 & 28.76 & - & 0.001 \\
\hline Monocytes (\%) & $4.21 \pm 0.16$ & 5.00 & 3.00 & $4.17 \pm 0.09$ & 5.00 & 3.00 & -11.87 & - & 0.002 \\
\hline
\end{tabular}

Abbreviations: WBC, White blood cell count; RBC, red blood cell count; $\mathrm{HGB}$, hemoglobin; $\mathrm{HCT}$, hematocrit; $\mathrm{MCV}$, mean corpuscular volume; $\mathrm{MCH}$, mean corpuscular hemoglobin mass; $\mathrm{MCHC}$, mean corpuscular hemoglobin concentration; PLT, platelets count; RDW-CV, red blood cell distribution width-coefficient of variation; PDW, platelet distribution width; MPV, mean platelet volume.

\section{Discussion}

Occupational exposure to toxic metals such as lead possesses serious health risks. Adverse effects of exposure to lead on human health are well known. Most previous studies have reported an association between lead- related dis- 
eases and $\mathrm{PbB}$ levels, but some of the relationships have not posed this association $(8,14,22-27)$. Therefore, in the present matched case-control study, the occupational and biological exposures to lead were assessed to examine the association of occupational PbB levels with hematological parameters and kidney function in mine workers.

There is no safe level of $\mathrm{PbB}$, but significant leadinduced hematological disorders, like anemia, happen when the PbB levels are higher than the threshold limits. In this study, the mean level of PbB in the exposed group was three times higher than in the non- exposed group. The overall mean PbB level was estimated to be $33.20 \mu \mathrm{g} / \mathrm{dL}$ for the studied mine workers (exposed group), and $88.57 \%$ of them ( 62 workers) had a PbB concentration of higher than $20 \mu \mathrm{g} / \mathrm{dL}$. Therefore, the mean PbB level in exposed workers was more than the recommended level by the WHO and $\operatorname{ACGIH}(20 \mu \mathrm{g} / \mathrm{dL})(28)$.

Due to the release of lead through smelter emission, gasoline exhausts, peeling paints, etc., it never disappears completely from our environment. Therefore, in the present study, the low level of lead in the blood of the nonexposed group was detected, as well. Exposure of the general population to lead mostly occurs through the ingestion of contaminated food and drinking water, as well as by the inhalation of particulate lead in ambient air (29). Lead enters the bloodstream after it is absorbed. First, lead attaches to proteins in the blood and is carried to different tissues or organs in the body. The high amount of lead in the blood binds to the red blood cell and impairs the formation of "heme", which is extremely important to life because it carries oxygen to tissues of the body. Lead interferes with the production of this substance at several different steps (30). In this regard, comparing the obtained biomarkers in the exposed group and non-exposed workers, some lead-induced changes were approved. Data analysis showed that in chronic exposure with the PbB level in the range of 10 to $35 \mu \mathrm{g} / \mathrm{dL}$, the $\mathrm{RBC}$ and $\mathrm{HGB}$ changes in the exposed group relative to the non-exposed group were $6.33 \%$ and $-1.76 \%$, respectively. Our finding is consistent with previously published observations (31).

All red cell indices are useful to evaluate the etiology of anemia. Anemia is defined as a low level of hemoglobin and is related to a reduced HTC value, which is defined as the ratio of red blood cell volume to the total blood volume $(14,32)$.

Although the mean value of measured CBC parameters was within the normal range, the values of the mentioned parameters in some of the exposed workers were lower than the recommended level. Previous studies have shown that lead-induced anemia such as microcytic or normocytic, hypochromic can be easily diagnosed at the PbB levels higher than $50 \mu \mathrm{g} / \mathrm{dL}$ in adults, and hence chronic expo- sure to lead did not significantly affect the RBC count; however seemed that the exposure to lead decreased the levels of RDW-CV, MCV, HGB, MCH, and hematocrit (HCT) parameters in the exposed group $(13,33,34)$. In addition to the decreased level of MCHC, the significant correlation between the PbB levels and U-ALA, U-coproporphyrin, and B-ZPP can be considered as a warning and the symptom of the beginning of lead-induced heme biosynthesis impairment and anemia, resulting in the increased levels of urinary ALA and coproporphyrin in lead mine workers. Based on the results, it seems that the MCHC index is a more sensitive marker than the hemoglobin level for the adverse effects of chronic lead exposure on erythrocytes and hence, it can be used as a useful parameter during prophylactic medical examinations of occupationally lead-exposed workers.

Lead generally inhibits the delta-aminolevulinic acid dehydratase activity, which enhances ALA in blood plasma and urine, and it is considered the most sensitive biomarker for the adverse effects of lead exposure. It should be noted that heme biosynthesis in the human body is not decreased until ALAD activity is largely inhibited $(8,14)$. On the other hand, a significant rise in ZPP in the exposed group indicated the disturbance in the final step of heme biosynthesis. This finding is in agreement with the results of other studies (14).

The results of this study indicated that the relationships between lead exposure and MCV, MCH, PLT, MPV, and eosinophil parameters are dependent on the exposure duration. Therefore, the values of MCH, MCV, PLT, and MPV indices were decreased with each one-year increase in chronic exposure to lead, but the eosinophil percentage was increased. Chronic exposure to lead in the workplace is associated with an increased risk of anemia. As mentioned above, cumulative lead poisoning leads to the disruption of enzymatic processes in the synthesis pathway of heme (ALAD enzyme) that subsequently inhibits the ability to produce hemoglobin. This phenomenon reduces the number of complete blood cells (such as MCV, MCH, PLT, and MPV parameters) and increases the risk of anemia (35, 36). Anemia associated with chronic lead exposure is the result of both interfering with heme biosynthesis and reduced survival of red blood cells (24).

Data analysis indicated that the changes in the PbB levels were negatively correlated with the changes in RDW-CV, PDW, lymphocytes, and eosinophils, but a positive correlation was achieved between the PbB levels and the changes in RBC, WBC, MCHC, HCT, and MPV. Previous studies (22) reported that the change in the PbB level due to acute lead exposure was negatively correlated with the changes in $\mathrm{RBC}$, and positively correlated with the changes in MCV and $\mathrm{RDW}-\mathrm{CV}$. Chronic exposure to lead can cause a decrease in the level of RDW-CV, MCV, HGB, MCH, and HCT parameters 
in exposed subjects, while it does not significantly affect the RBC count $(13,33,34)$. Acute exposure to lead (PbB levels $\geq 50 \mu \mathrm{g} / \mathrm{dL}$ ) quickly affects red blood cells and decreases their counts shortly after exposure due to the inhibition of ALAD activity. However, the heme-biosynthesis does not decrease until the activity of ALAD is inhibited by $80-90 \%$ (8).

Katavolos et al. demonstrated that MCHC and hemoglobin concentrations decreased significantly with rising $\mathrm{PbB}$ concentrations (25). The results of this study indicated a significant negative correlation between the concentration of $\mathrm{PbB}$ and the Hb and MCV levels after controlling for potential confounders (age, weight, smoking, and alcohol consumption). This finding may be due to the effect of chronic lead exposure that inhibits the production of hemoglobin by interfering with enzymatic steps in the "heme" synthesis pathway, which decreases red blood cells, resulting in the increased risk of anemia. On the other hand, the absorption of lead can cause iron deficiency in the body, and subsequently increase the risk of anemia (37).

Anemia may be classified as macrocytic, normocytic, or microcytic based on the size of red blood cells (MCV), which is proportional to the amount of hemoglobin per red blood cells (MCH) (38). Anemia is defined as a low level of hemoglobin and is related to a reduced HTC value, which is defined as the ratio of the RBC volume to the total blood volume (39). Additionally, anemia may be described as hypochromic when the MCHC value is decreased. Anemia may be associated with anisocytosis when the coefficient of variation of the red blood cell volume distribution (RDW-CV) is increased (40).

On the other hand, the kidney is the critical organ for long-term occupational or environmental exposure to lead, and excessive exposure may result in nephrotoxic effects. In this study, renal function was investigated by determining blood urea, creatinine, and urinary creatinine levels. The results implied a significant correlation between the $\mathrm{PbB}$ level and B-creatinine level and urinary creatinine. Kim et al., in a longitudinal study, reported a significant association between the increase of $\mathrm{PbB}$ levels and reduced renal function measured by serum creatinine concentrations or creatinine clearance in the general population (41). It is worth noting that the simultaneous inhalation exposure to dust of other heavy metals in lead mines can cause potential or synergist effects on the blood and kidney disorders. In this regard, the lack of investigating the effects of other metals on mine workers is considered a limitation of this study.

As the duration of exposure lengthens, and the worker is subjected to several active episodes of poisoning, the creatinine clearance also becomes progressively worse (42, 43). Therefore, in addition to PbB levels, the years of ex- posure to lead should be considered an important parameter in evaluating lead-induced renal disorders. A 10-fold increase in $\mathrm{PbB}$ (e.g., from 3 to $30 \mu \mathrm{g} \mathrm{Pb} / \mathrm{dL}$ ) was associated with an increase of $20.9 \mathrm{~g} / \mathrm{L}$ in B-urea, and each oneyear increase in occupational exposure to lead was associated with an increase of $0.508 \mathrm{~g} / \mathrm{L}$ in B-urea. Previous studies have reported that the $\mathrm{PbB}$ level of $60 \mu \mathrm{g} / \mathrm{dL}$ is the threshold for proximal tubular damage in both animal and human studies $(33,44)$. Human studies showed that the overall dose-effect pattern suggests an increasing severity of nephrotoxicity associated with increasing $\mathrm{PbB}$, with diminished creatinine and urea filtration evident at PbBs of lower than $10 \mu \mathrm{g} / \mathrm{dL}$ (45).

It should be noted that although the measurement of the $\mathrm{PbB}$ level is introduced as a precise biological exposure index for the evaluation of occupational exposure to lead, the measurement of this index requires invasive sampling and access to expensive equipment. Excessive costs and access to advanced laboratory equipment are the most important restrictions and limitations to the implementation of biological monitoring for workers in developing countries; however, in some cases, by focusing on specific biological exposure indices, the implementation of the biological processes for workers exposed to hazardous chemical compounds will be difficult $(46,47)$. Measuring U-ALA and U-coproporphyrin does not require invasive sampling, and can be done using routine laboratory equipment. For measuring B-ZPP, although it requires invasive sampling, with the availability of routine laboratory equipment, it is possible to measure it (48). Various studies indicated that the B- ZPP level is an appropriate indicator for chronic exposure to lead $(11,49)$. Therefore, if necessary, B-ZPP, U-ALA, and U-coproporphyrin indices can be effectively used as biological indicators of chronic exposure to lead.

The strengths of the present study were the evaluation of various biological indices of hematological parameters and renal function due to occupational exposure to lead and the study of the effect of occupational exposure duration to lead and $\mathrm{PbB}$ levels on these biological indices to determine the appropriate biological index. Restrictions and weaknesses of the present study included the lack of the measurement of lead concentration in the inhaled air of workers, lack of measurement of exposure to other heavy metals, limited number of studied workers, and lack of measurement of biological indices of hematological parameters and renal function in the workers of other leadcontaminated workplaces. We could not control the other possible sources of lead exposure outside the workplace and obtain comprehensive information regarding the previous experience of lead-related work for the participants. However, it should be noted that for lead-mine workers, environmental exposure to lead is relatively less severe than 
Table 2. The Changes in Complete Blood Count (CBC) Parameters with PbB Level and Years of Occupational Exposure to Lead After Controlling for Confounding Factors (Reference: Non-exposed employees $=1$ )

\begin{tabular}{|c|c|c|c|}
\hline Variable & $\mathrm{OR}_{\text {Adjusted }}\left(95 \% \mathrm{CI}^{\mathrm{a}}\right)$ & Std. Error & P-Value \\
\hline \multicolumn{4}{|l|}{ WBC } \\
\hline $\mathrm{PbB}^{\mathrm{b}}$ & $0.98(-0.05-3.142)$ & 0.15 & 0.743 \\
\hline $\mathrm{ED}^{\mathrm{c}}$ & $0.95(-0.07-2.731)$ & 0.32 & 0.061 \\
\hline \multicolumn{4}{|l|}{$\mathbf{R B C}$} \\
\hline $\mathrm{PbB}$ & $1.00(-0.005-1.013)$ & 0.005 & 0.384 \\
\hline ED & $1.01(-0.001-1.021)$ & 0.007 & 0.061 \\
\hline \multicolumn{4}{|l|}{ HB } \\
\hline $\mathrm{PbB}$ & $0.99(-0.061-0.044)$ & 0.026 & 0.753 \\
\hline $\mathrm{ED}$ & $0.98(-0.075-0.034)$ & 0.027 & 0.460 \\
\hline \multicolumn{4}{|l|}{ HCT } \\
\hline $\mathrm{PbB}$ & $0.93(-0.199-0.060)$ & 0.065 & 0.288 \\
\hline $\mathrm{ED}$ & $0.96(-0.194-0.190)$ & 0.079 & 0.639 \\
\hline \multicolumn{4}{|l|}{ MCV } \\
\hline $\mathrm{PbB}$ & $0.99(-0.395-0.100)$ & 0.127 & 0.265 \\
\hline ED & $0.64(-0.635-0.120)$ & 0.130 & $0.005^{d}$ \\
\hline \multicolumn{4}{|l|}{ МCH } \\
\hline $\mathrm{PbB}$ & $0.98(-0.143-0.064)$ & 0.052 & 0.447 \\
\hline ED & $0.86(-0.025-0.047)$ & 0.053 & $0.005^{d}$ \\
\hline \multicolumn{4}{|l|}{ MCHC } \\
\hline $\mathrm{PbB}$ & $1.00(-0.008-0.027)$ & 0.009 & 0.304 \\
\hline $\mathrm{ED}$ & $-0.96(-0.073-0.003)$ & 0.019 & 0.074 \\
\hline \multicolumn{4}{|l|}{ PLT } \\
\hline $\mathrm{PbB}$ & $0.81(-0.866-3.80)$ & 1.17 & 0.215 \\
\hline ED & $0.89(-0.830-0.66)$ & 0.962 & $0.005^{d}$ \\
\hline \multicolumn{4}{|l|}{ RDW } \\
\hline $\mathrm{PbB}$ & $1.02(-0.005-0.054)$ & 0.015 & 0.070 \\
\hline ED & $1.11(-0.011-0.042)$ & 0.013 & 0.225 \\
\hline \multicolumn{4}{|l|}{ PDW } \\
\hline $\mathrm{PbB}$ & $0.99(-0.015-0.012)$ & 0.007 & 0.843 \\
\hline ED & $1.01(-0.012-0.033)$ & 0.011 & 0.367 \\
\hline \multicolumn{4}{|l|}{ MPV } \\
\hline $\mathrm{PbB}$ & $0.88(-0.038-0.001)$ & 0.009 & $0.035^{d}$ \\
\hline ED & $1.01(-0.027-0.065)$ & 0.023 & 0.415 \\
\hline \multicolumn{4}{|c|}{ Neutrophils } \\
\hline $\mathrm{PbB}$ & $0.98(-0.633-0.269)$ & 0.227 & 0.425 \\
\hline ED & $0.99(-0.472-0.232)$ & 0.177 & 0.50 \\
\hline \multicolumn{4}{|c|}{ Lymphocytes } \\
\hline $\mathrm{PbB}$ & $1.01(-0.130-0.277)$ & 0.103 & 0.474 \\
\hline ED & $0.95(-0.205-1.465)$ & 0.169 & 0.433 \\
\hline \multicolumn{4}{|l|}{ Eosinophils } \\
\hline $\mathrm{PbB}$ & $1.12(-0.009-0.037)$ & 0.007 & $0.001^{d}$ \\
\hline ED & $1.01(-0.020-0.047)$ & 0.017 & 0.425 \\
\hline \multicolumn{4}{|l|}{ Monocytes } \\
\hline $\mathrm{PbB}$ & $1.00(-0.024-0.014)$ & 0.01 & 0.603 \\
\hline ED & $0.99(-0.056-0.039)$ & 0.024 & 0.720 \\
\hline
\end{tabular}

Abbreviations: CI, Confident interval; PbB, Blood lead level.

${ }^{a}$ Adjusted for age, weight, smoking, and alcohol consumption,

b Blood lead level.

${ }^{c}$ Years of occupational exposure to lead.

${ }^{\mathrm{d}}$ Significant correlation at P-value $<0.05$.
Table 3. The Changes in the Blood Synthesis and Renal Function Biomarkers with $\mathrm{PbB}$ Levels and Duration of Occupational Exposure to Lead After Controlling for Confounding Factors (Reference: Non-exposed employees $=1$ )

\begin{tabular}{|c|c|c|c|}
\hline Variable & $\mathrm{OR}_{\text {Adjusted }}\left(\mathbf{9 5} \% \mathrm{CI}^{\mathrm{a}}\right)$ & Std. Error & P-Value \\
\hline \multicolumn{4}{|l|}{ B-urea } \\
\hline $\mathrm{PbB}^{\mathrm{b}}$ & $1.23(0.031-0.388)$ & 0.09 & $0.022^{d}$ \\
\hline $\mathrm{ED}^{\mathrm{c}}$ & $1.66(0.251-0.917)$ & 0.206 & $0.015^{d}$ \\
\hline \multicolumn{4}{|l|}{ B-creatinine } \\
\hline $\mathrm{PbB}$ & $0.99(-0.013-0.003)$ & 0.004 & 0.259 \\
\hline ED & $1.00(-0.013-0.060)$ & 0.005 & 0.492 \\
\hline \multicolumn{4}{|l|}{ B-ZPP } \\
\hline $\mathrm{PbB}$ & $1.57(5.96-9.18)$ & 1.31 & $0.000^{d}$ \\
\hline ED & $0.90(-3.32-3.12)$ & 1.62 & 0.951 \\
\hline \multicolumn{4}{|l|}{ U-ALA } \\
\hline $\mathrm{PbB}$ & $1.14(0.106-0.164)$ & 0.015 & $0.000^{d}$ \\
\hline ED & $0.99(-0.081-0.035)$ & 0.029 & 0.436 \\
\hline \multicolumn{4}{|c|}{ U-coproporphyrin } \\
\hline $\mathrm{PbB}$ & $1.82(15.37-19.59)$ & 2.30 & $0.000^{d}$ \\
\hline ED & $1.00(-4.890-6.380)$ & 2.84 & 0.793 \\
\hline \multicolumn{4}{|l|}{ U-creatinine } \\
\hline $\mathrm{PbB}$ & $1.24(0.161-0.227)$ & 0.022 & $0.000^{d}$ \\
\hline ED & $1.00(-0.065-0.079)$ & 0.063 & 0.845 \\
\hline
\end{tabular}

a Adjusted for age, weight, smoking, and alcohol consumption.

${ }^{b}$ Blood lead level

${ }^{\mathrm{c}}$ Years of occupational exposure to lead.

${ }^{\mathrm{d}}$ Significant correlation coefficient at P-value $<0.025$

its occupational exposure.

\subsection{Conclusion}

Chronic occupational exposure to lead is usually associated with a wide range of easily preventable health problems. Our results demonstrated that lead exposure did not significantly affect the values of RBC counts but decreased RDW-CV, MCH, MCV, HGB, and HCT, and simultaneously increased the values of U-ALA, U-coproporphyrin, and B-ZPP in exposed subjects in a time and dose-dependent manner. Given these results, a regular assessment of commonly available parameters of blood cell morphology and renal function markers should be performed to monitor the toxic effects of lead. Therefore, for the early detection of hematological and renal effects of occupational lead exposure, it is proposed to study the heme biosynthesis biomarkers, CBC parameters (especially MCV, MCH, HCT, HGB, and MPV), creatinine, and urea indices as biological indicators of chronic exposure to lead. 


\section{Acknowledgments}

The authors would like to express their gratitude to the Vice-President of Research and Technology of Larestan Faculty of Medical Sciences, as well as the mine workers. The present paper was extracted from a research project (No. 1396-223), approved by the Ethics Committee of Larestan Medical Faculty.

\section{Footnotes}

Authors' Contribution: Data analysis, project design, data acquisition in Yazd province: Razzagh Rahimpoor; Data analysis and project design: Mohammad Reza Zare; Drafting of the manuscripts in Persian and revising the manuscript in English: Maryam Rostami Aghdam Shendi; Quality control of data and revising the manuscript in English: Mohammad Javad Assari; Data analysis: Ahmad Mirzaei; All authors read and approved the final manuscript.

Conflict of Interests: There is no conflict of interest.

Ethical Approval: The present study was reviewed and approved by the Institutional Review Board and Ethics Committee of Larestan University of Medical Sciences (Ethical code: IR.LARUMS.REC.1396.223) before the study in 2018, and written informed consent was obtained from the participants. Permission was obtained from the mine authorities, and the purpose of the study was explained to all participants. They were also assured of data confidentiality, and all the samples and questionnaires were kept anonymous.

Funding/Support: This work was supported by the VicePresident of Research and Technology of Larestan Faculty of Medical Sciences.

\section{References}

1. Jalali M, Aliabadi M, Farhadian M, Negahban SA. Investigation of the variation ofurine densityas abiomarker of dehydrationconditionsin workers employed in hotworkplaces. Iran Occup Health J. 2014;11(2):99-110.

2. Moradpour Z, Ghorbani Shahna F, Bahrami A, Soltanian A, Hesam G. Evaluation of volatile organic compounds at petrochemical complexes in Iran. Health Scope. 2017;6(4). doi: 10.5812/jhealthscope.62595.

3. Rahimpoor R, Bahrami AR, Assari MJ, Ghorbani F, Negahban AR, Rahimnejad S, et al. Biological monitoring of petrochemical industry workers exposed to benzene, toluene, xylenes, methyl ethyl ketone, and phenol in Southern Iran.J Occup Health Epidemiol. 2014;3(2):62-71. doi: 10.18869/acadpub.johe.3.2.62.

4. Solgi E, Khodabandelo H. Cadmium and lead disruption in soils around the hegmatan cement factory, Iran. Health Scope. 2016;5(2). doi: $10.17795 /$ jhealthscope-34184.

5. Reh $\mathrm{BD}$, Weber J. Health hazard evaluations; occupational exposure to lead, 1994 to 1999. CDC; 2005. Available from: https://stacks.cdc.gov/ view/cdc/6940.
6. Tong S, von Schirnding YE, Prapamontol T. Environmental lead exposure: a public health problem of global dimensions. Bull World Health Organ. 2000;78(9):1068-77. [PubMed: 11019456]. [PubMed Central: PMC2560844].

7. Vaglenov A, Creus A, Laltchev S, Petkova V, Pavlova S, Marcos R. Occupational exposure to lead and induction of genetic damage. Environ Health Perspect. 2001;109(3):295-8. doi: 10.1289/ehp.01109295. [PubMed: 11333192]. [PubMed Central: PMC1240249].

8. Hormozi M, Mirzaei R, Nakhaee A, Payandeh A, Izadi S, Dehghan Haghighi J, et al. Quantification of urinary metabolites of toluene and xylene isomers as biological indices of occupational exposure in printing industry workers. Health Scope. 2019;8(1). doi: 10.5812/jhealthscope.82962.

9. International Agency for Research on Cancer: IARC. Overall evaluation of carcinogenicity: An updating of IARC monographs. IARC; 1987.

10. Yilmaz H, Keten A, Karacaoglu E, Tutkun E, Akcan R. Analysis of the hematological and biochemical parameters related to lead intoxication. J Forensic Leg Med. 2012;19(8):452-4. doi: 10.1016/j.jflm.2012.04.001. [PubMed: 23084307].

11. Yu C, Lin J, Lin-Tan D. Environmental exposure to lead and progression of chronic renal diseases: a four-year prospective longitudinal study. JAm Soc Nephrol. 2004;15(4):1016-22. [PubMed: 12540640].

12. Pachathundikandi SK, Varghese ET. Blood zinc protoporphyrin, serum total protein, and total cholesterol levels in automobile workshop workers in relation to lead toxicity: Our experience. Indian J Clin Biochem. 2006;21(2):114-7. doi: 10.1007/BF02912924. [PubMed: 23105626]. [PubMed Central: PMC3453998].

13. Patrick L. Lead toxicity, a review of the literature. Part 1: Exposure, evaluation, and treatment. Altern Med Rev. 2006;11(1):2-22. [PubMed: 16597190].

14. Chwalba A, Maksym B, Dobrakowski M, Kasperczyk S, Pawlas N, Birkner E, et al. The effect of occupational chronic lead exposure on the complete blood count and the levels of selected hematopoietic cytokines. Toxicol Appl Pharmacol. 2018;355:174-9. doi: 10.1016/j.taap.2018.05.034. [PubMed: 29857081].

15. Kianoush S, Balali-Mood M, Mousavi SR, Shakeri MT, Dadpour B, Moradi V, et al. Clinical, toxicological, biochemical, and hematologic parameters in lead exposed workers of a car battery industry. Iran J Med Sci. 2013;38(1):30-7. [PubMed: 23645955]. [PubMed Central: PMC3642942].

16. Hermanus MA. Occupational health and safety in mining-status, new developments, and concerns. J South Afr Inst Min Metall. 2007;107(8):531-8.

17. Brown TJ, Bide T, Hannis SD, Idoine NE, Hetherington LE, Shaw RA, et al. World mineral production 2004-2008. British Geological Survey; 2010.

18. Fong-Sam Y, Kuo CS, Shi L, Tse P, Wacaster SG, Wilburn DR, et al. The mineral industries of Asia and the Pacific. Minerals Yearbook. 2008.

19. Monjezi M, Shahriar K, Dehghani H, Samimi Namin F. Environmental impact assessment of open pit mining in Iran. Environ Geol. 2009;58(1):205-16. doi:10.1007/s00254-008-1509-4.

20. Tomokuni K, Ichiba M, Hirai Y, Hasegawa T. Optimized liquidchromatographic method for fluorometric determination of urinary delta-aminolevulinic acid in workers exposed to lead. Clin Chem. 1987;33(9):1665-7. [PubMed: 3621570].

21. Tomokuni K, Ichiba M, Hirai Y, Sugimoto K, Yoshida T, Hirata M. Comparison between the fluorometric HPLC method and the conventional method for determining urinary delta-aminolevulinic acid and coproporphyrin as indices of lead exposure. Int Arch Occup Environ Health. 1988;61(3):153-6. doi: 10.1007/BF00381011. [PubMed: 3220586].

22. Dobrakowski M, Boron M, Czuba ZP, Birkner E, Chwalba A, Hudziec E, et al. Blood morphology and the levels of selected cytokines related to hematopoiesis in occupational short-term exposure to lead. Toxicol Appl Pharmacol. 2016;305:111-7. doi: 10.1016/j.taap.2016.06.015. [PubMed: 27298078]. 
23. Garzillo EM, Lamberti M, Genovese G, Pedata P, Feola D, Sannolo $\mathrm{N}$, et al. Blood lead, manganese, and aluminum levels in a regional Italian cohort of ALS patients: does aluminum have an influence? J Occup Environ Med. 2014;56(10):1062-6. doi: 10.1097/JOM.0000000000000266. [PubMed: 25285828].

24. Hsieh NH, Chung SH, Chen SC, Chen WY, Cheng YH, Lin YJ, et al. Anemia risk in relation to lead exposure in lead-related manufacturing. BMC Public Health. 2017;17(1):389. doi: 10.1186/s12889-017-4315-7. [PubMed: 28476140]. [PubMed Central: PMC5420139].

25. Katavolos P, Staempfli S, Sears W, Gancz AY, Smith DA, Bienzle D. The effect of lead poisoning on hematologic and biochemical values in trumpeter swans and Canada geese. Vet Clin Pathol. 2007;36(4):341-7. doi: 10.1111/j.1939-165x.2007.tb00438.x. [PubMed: 18041699].

26. Suzen HS, Duydu Y, Aydin A, Isimer A, Vural N. Influence of the deltaaminolevulinic acid dehydratase (ALAD) polymorphism on biomarkers of lead exposure in Turkish storage battery manufacturing workers. Am J Ind Med. 2003;43(2):165-71. doi: 10.1002/ajim.10158. [PubMed: 12541271].

27. Svecevicius G, Sauliute G, Idzelis RL, Grigeleviciute J. Accumulation of heavy metals in different body tissues of Atlantic salmon, Salmo salar L., exposed to a model mixture ( $\mathrm{Cu}, \mathrm{Zn}, \mathrm{Ni}, \mathrm{Cr}, \mathrm{Pb}, \mathrm{Cd})$ and singly to nickel, chromium, and lead. Bull Environ Contam Toxicol. 2014;92(4):440-5. doi: 10.1007/s00128-014-1237-2. [PubMed: 24584166].

28. Prüss-Üstün A, Corvalán C. Preventing disease through healthy environments. USA: Towards an estimate of the environmental burden of disease. Geneva: WHO; 2006. Available from: https://www.who.int/ quantifying_ehimpacts/publications/preventingdisease.pdf.

29. D’Souza H S, Dsouza SA, Menezes G, Venkatesh T. Diagnosis, evaluation, and treatment of lead poisoning in general population. Indian J Clin Biochem. 2011;26(2):197-201. doi: 10.1007/s12291-011-0122-6. [PubMed: 22468050]. [PubMed Central: PMC3107416].

30. Jang WH, Lim KM, Kim K, Noh JY, Kang S, Chang YK, et al. Low level of lead can induce phosphatidylserine exposure and erythrophagocytosis: a new mechanism underlying lead-associated anemia. Toxicol Sci. 2011;122(1):177-84. doi:10.1093/toxsci/kfr079. [PubMed: 21482638].

31. Pourabdian S, Eizadi-Mood N, Golshiri P, Amini F. The relationship between blood lead level and neuro-psychological and hematological findings in lead-exposed workers of battery industry. Iran JToxicol. 2011;5(14):521-6.

32. Billett HH; rd. Hemoglobin and hematocrit. In: Walker HK, Hall WD, Hurst JW, editors. Clinical methods: The history, physical, and laboratory examinations. Boston; 1990.

33. Flora G, Gupta D, Tiwari A. Toxicity of lead: A review with recent updates.Interdiscip Toxicol.2012;5(2):47-58. doi:10.2478/v10102-012-00092. [PubMed: 23118587]. [PubMed Central: PMC3485653].

34. Vanisthasree K, Reddy AG, Kalakumar B, Haritha C, Anilkumar B. Hepatotoxicity studies in the progeny of pregnant dams treated with methimazole, monocrotophos and lead acetate. Toxicol Int. 2011;18(1):679. doi: 10.4103/0971-6580.75868. [PubMed: 21430926]. [PubMed Central: PMC3052590].

35. Keramati MR, Manavifar L, Badiee Z, Sadeghian MH, Farhangi $H$ Mood MB. Correlation between blood lead concentration and iron deficiency in Iranian children. Niger Med J. 2013;54(5):325-8. doi:
10.4103/0300-1652.122353. [PubMed: 24403711]. [PubMed Central: PMC3883233].

36. Hsieh LL, Liou SH, Chen YH, Tsai LC, Yang T, Wu TN. Association between aminolevulinate dehydrogenase genotype and blood lead levels in Taiwan. J Occup Environ Med. 2000;42(2):151-5. doi 10.1097/00043764-200002000-00009. [PubMed: 10693075].

37. Agency for Toxic Substances and Disease Registry (ATSDR). Toxicolog ical profile for lead (atlanta, ga: Us department of health and human services, agency for toxic substances and disease registry (ATSDR), public health service). US EPA (2006) Air quality criteria for lead. 2007.

38. Sarma PR. Red cell indices. Clinical methods: The history, physical, and laboratory examinations. 3rd ed. Butterworths; 1990.

39. Beutler E, Waalen J. The definition of anemia: what is the lower limit of normal of the blood hemoglobin concentration? Blood. 2006;107(5):1747-50. doi: 10.1182/blood-2005-07-3046. [PubMed 16189263]. [PubMed Central: PMC1895695].

40. Milman N. Postpartum anemia I: definition, prevalence, causes, and consequences. Ann Hematol. 2011;90(11):1247-53. doi: 10.1007/s00277011-1279-z. [PubMed: 21710167].

41. Kim R, Rotnitsky A, Sparrow D, Weiss S, Wager C, Hu H. A longitudinal study of low-level lead exposure and impairment of renal function. The Normative Aging Study. JAMA. 1996;275(15):1177-81. [PubMed: 8609685].

42. Alasia DD, Emem-Chioma PC, Wokoma FS. Association of lead exposure, serum uric acid and parameters of renal function in Nigerian lead-exposed workers. Int J Occup Environ Med (The IJOEM). 2010;1(4).

43. Brand P, Gube M, Gerards K, Bertram J, Kaminski H, John AC, et al. Internal exposure, effect monitoring, and lung function in welders after acute short-term exposure to welding fumes from different welding processes. J Occup Environ Med. 2010;52(9):887-92. doi 10.1097/JOM.0b013e3181f09077. [PubMed: 20798644]

44. Loghman-Adham M. Renal effects of environmental and occupational lead exposure. Environ Health Perspect. 1997;105(9):928-38. doi: 10.1289/ehp.97105928. [PubMed: 9300927]. [PubMed Central: PMC1470371].

45. Gidlow DA. Lead toxicity. Occup Med (Lond). 2015;54(2):348-56. doi: 10.1093/occmed/kqh019. [PubMed: 15020724].

46. Koh D, Aw TC. Surveillance in occupational health. Occup Environ Med. 2003;60(9):705-10. 633. doi: 10.1136/oem.60.9.705. [PubMed: 12937199]. [PubMed Central: PMC1740637].

47. Mangadze T, Dalu T, William Froneman P. Biological monitoring in southern Africa: A review of the current status, challenges and future prospects. Sci Total Environ. 2019;648:1492-9. doi 10.1016/j.scitotenv.2018.08.252. [PubMed: 30340294].

48. Lamola AA, Joselow M, Yamane T.Zinc protoporphyrin (ZPP): a simple, sensitive fluorometric screening test for lead poisoning. Clin Chem. 1975;21(1):93-7. [PubMed: 1116283].

49. Patil AJ, Bhagwat VR, Patil JA, Dongre NN, Ambekar JG, Jailkhani R, et al. Effect of lead $(\mathrm{Pb})$ exposure on the activity of superoxide dismutase and catalase in battery manufacturing workers (BMW) of Western Maharashtra (India) with reference to heme biosynthesis. Int J Environ Res Public Health. 2006;3(4):329-37. doi: 10.3390/ijerph2006030041. [PubMed: 17159274]. 